W części trzeciej - dotyczącej zagadnień symbolicznych - zajęto się głównie wpływem lasu na świat duchowy człowieka, jego wierzenia i obrzędowość. Podjęto również próbę wytłumaczenia mechanizmów kształtowania się tych zjawisk. Podstawowym materiałem badawczym były źródła etnograficzne, ale sięgnięto również do nielicznych zapisów kronikarskich, odnoszących się do lasów i drzew.

Interesująco przedstawia się porównanie częstotliwości pojawiania się poszczególnych gatunków drewna w średniowiecznym materiale archeologicznym $z$ aurą drzew określoną na podstawie źródeł etnograficznych. Omawiając wierzenia i przesądy związane z drzewami i krzewami podzieliłem je na trzy główne, aczkolwiek nie zawsze autonomiczne, grupy: drzewa złe, neutralne i dobre. Dokonując tego podziału zrezygnowalem z wszelkich prób dociekania genezy poszczególnych przekazów oraz określenia ich ewentualnego pochodzenia. Uznalem, że w przeważającej większości jest to już niemożliwe. Starałem się jedynie pominą́ te wierzenia czy przesądy, które jednoznacznie wiązały się z innymi kręgami kulturowymi i tradycjami. Podstawowym kryterium podziału była nie tyle tematyka danego przekazu, ile jego wymowa-aura.

1. Grupy drzew wydzielone na podstawie ich aury pokrywają się z preferencjami surowcowymi w średniowiecznej Wielkopolsce. Drzewa postrzegane jako dobre wybierano chętnie, drzew złych natomiast unikano.

2. Preferencje surowcowe w średniowiecznej Wielkopolsce świadczą o dobrej znajomości właściwości technicznych poszczególnych rodzajów drewna i jak najbardziej celowym ich wykorzystywaniu. Potwierdzeniem tego mogą być zmiany składu gatunkowego zależnie od typu konstrukcji oraz funkcji wyrobu, z uwzględnieniem warunków, w jakich drewno ma przebywać i sił, jakie na nie będą działać. Dobór ten calkowicie odpowiada obecnej wiedzy o drewnie i jego właściwościach fizycznych, mechanicznych i technologicznych.

Wydaje się więc, że wierzenia, przesądy i podania ludowe związane z poszczególnymi drzewami mogły mieć w pewnym sensie charakter wtórny. To drzewo i jego właściwości użytkowe mogły znacząco wpływać i kształtować wierzenia z nim związane i sposób jego postrzegania. Wydaje się również, że negatywne podania związane z poszczególnymi rodzajami czy gatunkami drzew były efektem interpretacji przyczyn ich małej przydatności w gospodarce.

3. Na obraz drzewa lub krzewu miały wpływ nie tylko właściwości użytkowe jego drewna, ale również i inne użytki z niego czerpane. Przykładem może być leszczyna - orzechy, lipa kwiat, oraz drzewa owocowe - owoce.

Las prócz wartości gospodarczych i środowiskotwórczych jest także sam w sobie wartościa kulturową inspirującą i oddziałującą na wyobraźnię i potrzeby duchowe człowieka. Echa kulturotwórczej roli lasu odnajdujemy w mitologii, literaturze, muzyce, malarstwie i architekturze. Niniejsza praca jest próbą spojrzenia na to zjawisko oczami archeologa.

Tomasz Stępnik

\title{
ELEMENTY TEORII SPOLECZNEJ W ARCHEOLOGII - KONCEPCJE GRUP, INSTYTUCJI I STRUKTUR SPOLECZNYCH
}

\author{
(autoreferat wygłoszony w trakcie obrony pracy doktorskiej \\ w dniu 25 października 2000 r.)
}

Przedstawiona praca stanowi próbę szerszego zaprezentowania $w$ archeologii polskiej podstawowych zagadnień społecznych w odniesieniu do pradziejów i wczesnego średniowiecza oraz próbę oceny sposobów ich badania i rezultatów tych badań. Innymi słowy, w pracy chciałam 
ukazać silne i słabe strony poszczególnych koncepcji grup. instytucji i struktur społecznych oraz pokazać zalety ich praktycznych aplikacji.

Za punkt wyjścia mej pracy przyjęłam jedno z założeń neopragmatyzmu, mówiące, iż w nauce, $w$ tym również $w$ archeologii, istnieje wiele różnych sposobów rozwiązywania tych samych problemów badawczych. Sposobów tych, czyli różnych koncepcji, teorii, paradygmatów, nie można bezpośrednio porównywać ze sobą, gdyż każdy z nich operuje osobnym zbiorem reguł, innym językiem oraz charakteryzuje go inne podejście do danych. W tej sytuacji za jedyną metodę oceniania różnych koncepcji uznałam - za neopragmatystami - ocenę ich skuteczności i użyteczności, czyli konsekwencji praktycznych i teoretycznych, jakie za sobą pociagają. Stosując kryterium użyteczności do poszczególnych teorii, sprawdzałam, która najpełniej i w sposób najbardziej spójny wyjaśnia bądź interpretuje fragment przeszłej rzeczywistości społecznej.

W pracy pod pojęciem teorii rozumiem zarówno teorię w sensie ontologicznym, jak i epistemologicznym, zgodnie $z$ terminologią A.F. Grabskiego. Teoria w sensie ontologicznym, zwana także teorią przedmiotu poznania, obejmuje rezultaty badań, w naszym wypadku - pradziejów; w jej zakres wchodzą m.in. rozważania nad mechanizmami dziejów, ich istota, celem itd. Teoria w sensie epistemologicznym to teoria poznania, obejmujaca m.in. zagadnienia prawdy i obiektywizmu.

Mając tak ściśle sprecyzowane pojęcie teorii nietrudno na tej podstawie uszczególowić przedmiot badań, jakim jest teoria społeczna. W pracy pod pojęciem teorii społecznej rozumiałam: sposoby, główne założenia i rezultaty badań zjawisk życia społecznego w przeszłości. Same zjawiska społeczne ograniczyłam - jak zasygnalizowałam w tytule - do zagadnien wchodzących w skład socjologicznej teorii struktur społecznych i rozwoju spolecznego, czyli dokładniej - do zagadnień dotyczących jednostek, więzi między nimi, różnych form zbiorowego życia ludzi, zasad budowy struktury tych zbiorowości oraz procesów przemian zachodzących w tego rodzaju zbiorowościach.

Te zagadnienia stanowia podstawę konstrukcyjną poszczególnych rozdziałów mojej pracy. Rozdziały zaś, a właściwie cztery główne części pracy, odpowiadają podziałowi na cztery główne nurty badawcze: archeologii tradycyjnej, archeologii procesualnej, archeologii neomarksistowskiej i archeologii inspirowanej postmodernizmem i poststrukturalizmem. Podobny podział na cztery glówne nurty badawcze występuje w większości syntez archeologicznych, poczynając od pracy B. Triggera The History of Archaeological Thought, a kończąc na opublikowanym pod koniec roku 2000 podręczniku M. Johnsona Archaeological Theory. An Introduction.

Każdy $\mathrm{z}$ tych nurtów badawczych koncentrował się tylko na wybranych zagadnieniach społecznych, marginalizując pozostale. Pierwszym problemem, poruszanym przez przedstawicieli wszystkich nurtów, są próby identyfikacji rozmaitych grup na podstawie danych materialnych, poczynając od grup genetycznych, przez grupy językowe, hierarchie grup terytorialnych, po grupy zawodowe i grupy związane z plcią kulturową. Drugim problemem, zapoczątkowanym przez archeologów neomarksistowskich, jest próba identyfikacji instytucji spolecznych na podstawie pozostałości materialnych. Archeolodzy neomarksistowscy rozwinęli refleksję dotycząca natury władzy. Trzecim podjętym przez archeologów problemem jest zagadnienie rozwoju społecznego.

Dokładniej w ramach archeologii tradycyjnej zapoczątkowano i rozwinięto podstawowe metody identyfikacji różnego rodzaju grup terytorialnych i ich hierarchii oraz grup związanych ze stratyfikacją społeczną. Archeolodzy tradycyjni nie rozwinęli teorii odnoszącej się do funkcjonowania grup ludzkich w przeszłości. Zamiast tego dość często posługiwali się dowolnie przyjmowanymi analogiami etnograficznymi lub całymi schematami myślenia na temat hierarchii grup spolecznych, których nie można było zweryfikować opierając się na danych archeologicznych. W ten sposób na przykład wprowadzono do archeologii schematyczne, ewolucyjne ujęcie rozwoju społecznego, które - zamiast rozwinąć - zahamowalo na pewien czas refleksję nad tym zagadnieniem. 
Archeolodzy neomarksistowscy rozwinęli przede wszystkim teorie społeczne w sensie ontologicznym. Wprowadzili w zakres zainteresowań kwestiami społecznymi kilka nowych zagadnień, takich jak: nierówność spoleczna, władza. ideologia i związana z nimi dominacja. Niezwykle ważne okazały się idee zapożyczone z prac L. Althussera, M. Godeliera czy I. Wallersteina. Idee te pozwoliły postrzegać przeszłe formacje społeczne jako całości złożone ze względnie autonomicznych, a co za tym idzie - nieredukowalnych do siebie nawzajem struktur. W różnych społeczeństwach różne typy struktur mogły uzyskiwać dominującą rolę w ksztaltowaniu relacji społecznych. Archeolodzy najczęściej nadawali prymat strukturze ideologicznej i często nadmiernie eksponowali związki pokrewieństwa. Inspiracja dialektyka, rozumianą jako teoria rozwoju społecznego, pozwoliła ująć rozwój społeczny jako rezultat zaistnienia sprzeczności, ścierania się sprzecznych części składających się na całość formacji społecznej.

„Nowi Archeolodzy” i archeolodzy procesualni natomiast najbardziej rozszerzyli zakres zagadnień społecznych. Było to moźliwe dzięki zaakceptowaniu systemowej definicji kultury oraz optymistycznemu przekonaniu, że na podstawie źródeł archeologicznych możliwa jest rekonstrukcja wszystkich podsystemów kultury. Założono, że każdemu podsystemowi kultury można przypisać określone artefakty. Ponieważ za istotę kultury uznano zachowania ludzkie i efekty tych zachowań, zwrócono szczególną uwagę na relacje pomiędzy zachowaniami ludzkimi a układami artefaktów. Relacje te traktowano jako stałe, w związku z czym badania kwestii społecznych sprowadzono do poszukiwania materialnych wskaźników zachowań. Rozszerzono w tym celu repertuar metod badania grup społecznych znany $z$ archeologii tradycyjnej. Niepodważalnym osiagnięciem archeologii procesualnej jest rozwinięcie refleksji dotyczącej wymiany jako formy kontaktów międzyludzkich. Wymiana - rozumiana jako zjawisko znacznie szersze niż handel postrzegana jest jako akt społeczny kształtujący więzi społeczne pomiędzy jednostkami i grupami społecznymi. Archeolodzy procesualni nie rozwinęli odrębnego podejścia do kwestii rozwoju społecznego, traktując rozwój społeczny jako jeden z wielu elementów zmiany systemowej. Dlatego niezwykle trudne jest wyodrębnienie ze splotu procesów składających się na zmianę systemową samego rozwoju społecznego - jako odrębnego przedmiotu badań.

Osiagnięciem archeologii postprocesualnej jest zwrócenie uwagi na znaczenie ukryte za układem elementów kultury materialnej, istotne w konkretnych kontekstach społecznych. Dzięki wprowadzeniu tej nowej perspektywy badawczej ożywiono refleksję dotyczącą pewnych kategorii społecznych, przede wszystkim etniczności, oraz określono nowe kategorie społeczne, jak na przykład płeć kulturowa. Archeolodzy postprocesualni odrzucili możliwość tworzenia uogólnień na szerszą skalę, w wyniku czego nie rozwinięto refleksji dotyczącej rozwoju spolecznego.

Ponieważ nie sposób w tak krótkim wystąpieniu przedstawić wszystkich koncepcji i teorii dotyczących powyższych zagadnień, jako przykład zastosowania teorii społecznej w archeologii przedstawię rozumienie etniczności jako jednostki analizy społecznej w poszczególnych nurtach badawczych.

Od początku rozwoju archeologii tradycyjnej na określenie grup społecznych, wymiennie stosuje się pojęcia „etnos” i „lud”. Pojęcia te początkowo używane były intuicyjnie, bez definiowania, ponieważ refleksja teoretyczna nad badaniem etniczności rozwinęła się na szerszą skalę dopiero w latach 70., wraz $z$ narastaniem postaw krytycznych wobec dotychczasowego dorobku archeologii tradycyjnej.

Korzeni stosowanych pojęć można doszukiwać się w antropogeografii F. Ratzla. Prace Ratzla stanowiły zaplecze koncepcyjne niemiecko-austriackiej szkoły kulturowo-historycznej, w tym podstawy teoretyczne metody G. Kossinny oraz prac etnografa K. Moszyńskiego. „Lud” według F. Ratzla to przede wszystkim grupa ludzka o charakterze biologicznym, bezpośrednio zależna od natury, a charakteryzująca się wytworzoną przez siebie kultura jako rezultatem dostosowania się do określonych warunków środowiskowych i tych warunków do kultury, gdyż oddziaływanie 
środowisko - kultura jest u Ratzla dwustronne. Cechy kultury stały się podstawą określania odrębności ludów. Określaniu odrębności służyla również metoda geograficzna, wprowadzona do etnografii po raz pierwszy przez Ratzla. Substrakt biologiczny, kultura oraz metoda geograficzna stanowity podstawy definiowania etnosu w archeologii. Przykładowo dla W. Hensla etnos to kategoria historyczna o zmieniających się, ale w danym okresie wspólnych cechach biokulturowych, dysponujących określonym terytorium.

Ponieważ refleksja nad kulturą i podział na kulturę w sensie holistycznym i partytywnym zaistniał $w$ archeologii dopiero wraz $z$ rozwojem refleksji teoretycznej. początkowo automatycznie sprowadzono wspólnotę kulturową do kultury archeologicznej, dając przez to początek prostej lecz błędnej - identyfikacji jej z etnosem.

Ze względu na to, że rozwój archeologii tradycyjnej w wielu krajach był stymulowany czynnikami politycznymi, a zwłaszcza romantycznym nacjonalizmem $w$ Europie $i$ jego usiłowaniami ukazania długiej historii ludów i państw narodowych, również dane archeologiczne wykorzystywano w celu politycznego uzasadniania żądań ówcześnie istniejących grup do określonych terytoriów. W wielu syntezach archeologicznych wówczas tworzonych pod nazwy kultur archeologicznych podkładano treści etniczne, a następnie w przedstawianiu sytuacji w Europie od pradziejów po VIII/IX wiek przechodzono bezpośrednio do nazw narodów. Pozwala to sądzić, że etnos w pracach archeołogów traktowany był jako forma rozwojowa narodu. Naród zaś zastapił pojęcie etnosu w odniesieniu do czasów historycznych.

Najwcześniejszą metodą stosowaną w badaniu etnosów jest utożsamianie poszczególnych zabytków z nazwami etnosów znanymi ze źródeł pisanych. Na przykład w XIX wieku wszystkie przedmioty odkrywane na ziemiach polskich określano jako „słowiańskie”.

W latach 1860-1870 O. Montelius rozwiną tzw. bezpośrednią etnohistoryczną metodę usiłując prześledzić historie poszczególnych etnosów aż do głębokiej przeszlości, wykorzystując metodę retrogresywną wychodząc od momentu, gdy źródła historyczne można było zsynchronizować ze źródlami archeologicznymi.

$\mathrm{Na}$ procedurę badawczą archeologii środkowoeuropejskiej znaczny wpływ wywarł G. Kossinna, twórca metody osadniczo-archeologicznej, w 1974 roku nazwanej przez J. Żaka metodą etnoarcheologiczną. Metoda osadniczo-archeologiczna, pozwalająca na wyróżnianie prowincji kulturowych, opierala się na zalożeniu, że wyraźnie zdefinniowane i wyróżnione prowincje archeologiczne odpowiadają bez wątpienia terytoriom konkretnych ludów. Kossinna stosował metodę retrogresywną - pozwalająca przechodzić od historycznie znanych ludów do pozostałości materialnych $\mathrm{z}$ wcześniejszych okresów chronologicznych; metodę typologiczną - pozwalająca ustalić porządek chronologiczny pozostałości materialnych; metodę kartograficzną - w celu wyróżniania jednostek przestrzennych, jakimi byly prowincje kulturowe. W metodzie tej podstawa wyróżniania kultur archeologicznych są typy wytworów (a później cechy wytworów) o charakterze chronologicznym, wyróżnione w materialach z cmentarzysk i skarbów, częściowo z osad. Ujmowane przestrzennie wszelkie zwiazki formalne czasowe interpretowane sq $w$ kategoriach etnicznych, a każda zmiana w materiale archeologicznym ujmowana jest jako zmiana etnosu.

W polskiej archeologii tradycyjnej metoda ta została zmodyfikowana przez J. Kostrzewskiego i stosowana m.in. w badaniu etnogenezy Słowian. J. Kostrzewski twierdził, że ściśle określona kultura archeologiczna odpowiada powstałej w danym czasie odrębnej jednostce etnicznej, zauważyl jednak - w odróżnieniu od G. Kossinny - że następujące po sobie kultury archeologiczne, jeżeli są związane ze sobą licznymi wspólnymi cechami, odzwierciedlają różne etapy ewolucji tego samego etnosu, a nic są wyznacznikiem nowego etnosu.

Metodą tą posługiwano się w badaniu etnogenezy Slowian. J. Kostrzewski zajınując się etnogenezą jako punkt wyjścia przyjął zasięg Słowian we wczesnym średniowieczu. Analizując podobieństwa artefaktów w ramach następujących po sobie na obszarze Polski kultur archeologicznych 
uważał, że istnieje ciagłość kulturowa od III okresu epoki brązu do wczesnego średniowiecza. Kulturom archeologicznym przypisał przy tym sens etniczny; w ten sposób za prasłowiańską uznał kulturę łużycką, a także następujące po niej pozostałe kultury - pomorska, przeworska, oksywską.

Tę metodę zaadaptowano również do badań nad wcześniejszymi epokami, zwłaszcza nad neolitem. Na podstawie pozostałości materialnych starano się wyróżniać kultury archeologiczne. Przykładem takiego postępowania jest praca G. Childe'a The Danube in Prehistory, w której pozostałości materialne zostały przez autora podzielone na zespoły i kultury. Kultury nadal intuicyjnie utożsamiano $\mathrm{z}$ grupami społecznymi. Kultury archeologiczne traktowano przy tym jako podmioty na scenie historycznej, grające w prahistorii tę samą rolę, co w historii jednostki i grupy społeczne. Stąd bardzo często w pracach archeologicznych pojawiają się twierdzenia o wędrówce kultur, oddziaływaniu jednej kultury na drugą, upadku kultury.

Nieco inny obraz uzyskała ta procedura w przypadku badań nad paleolitem. W odniesieniu do paleolitu dolnego różnice w obrębie grupy narzędzi traktowano jako odzwierciedlenie zróżnicowania gatunkowego hominidów. W odniesieniu do paleolitu górnego zróżnicowanie w obrębie grupy narzędzi traktowano jako odrębne tradycje wytwórcze odzwierciedlające podział na grupy społeczne zamieszkujące i wędrujące razem.

W tej perspektywie badawczej kontrowersyjne jest właściwie wszystko, począwszy od samego faktu zaszeregowania tego typu badań. Z jednej strony badania te zalicza się do ogólniejszych badań nad kultura, $z$ drugiej strony uważa się je tylko za badania dotyczące społeczeństwa. Krytykę wzbudzają również założenia stosowanych metod. Zauważa się, że podobieństwa i różnice w przestrzennym rozkładzie artefaktów wynikać moga z wielu czynników, a tylko jednym z nich jest zróżnicowanie życia grupy ludzkiej w określonych warunkach. Zwrócono również uwagę na fakt, iż sama relacja pomiędzy kulturą materialną a etnosem powinna stać się przedmiotem badań, gdyż są to zasadniczo odrębne pojęcia. Potępiono również wykorzystywanie badań archeologicznych $w$ regionalnych lub lokalnych rozgrywkach politycznych.

Badania nad etnicznościa porzucono na rzecz innych zagadnień. Refleksji dotyczącej etniczności nie rozwijali archeolodzy neomarksistowscy. Archeolodzy procesualni potraktowali to zagadnienie marginalnie, co uwidoczniło się w dość rzadkiej ilości bezpośrednich odniesien do grup etnicznych w literaturze. W ramach archeologii procesualnej przetrwało nadawanie etnicznych etykietek odkrywanym miejscom i przedmiotom.

Na tym tle wyjątkiem jest praca K. Odnera dotycząca etnogenezy ludu Saami. Praca ta ukazuje $w$ innym, nowym świetle koncepcję etniczności. Etniczność ukazana jest w niej jako proces obejmujący uświadamianie sobie różnic pomiędzy grupami ludzkimi. Różnice te są stale kształtowane, $z$ jednej strony wpływają na interakcje między członkami różnych grup, jednocześnie są przez te interakcje reprodukowane i transformowane w procesie życia społecznego. Analiza Odnera przedmiotem badań czyni proces powstawania etniczności Saami i jej utrzymania dzięki interakcjom $z$ innymi grupami etnicznymi. Zdaniem autora etniczność Saami wyrosla z procesu różnicowania i specjalizacji ludów zamieszkujących obszar wokół Zatoki Fińskiej na początku naszej ery.

Praca Odnera zapowiada jakby późniejsze rozumienie etniczności jako tożsamości grupy społecznej i zrywa $z$ tradycyjnym łączeniem kultury archeologicznej $z$ etnosem. Ujęcie etniczności jako procesu zostało jednak skrytykowane jako zbyt szerokie, gdyż można je odnosić do każdej symbolicznie zróżnicowanej grupy z silnym poczuciem tożsamości, a więc też i do kategorii gender i do warstwy społecznej.

Szersze zainteresowanie etnicznością powróciło w ramach archeologii postprocesualnej, pod wpływem prac etnograficznych $\mathrm{i}$ antropologicznych. Taką przełomową praca, dająca początek nowemu odczytaniu etniczności, była praca F. Bartha Ethnic groups and boundaries. Wraz z nią nacisk $w$ definiowaniu etniczności przeniesiony został na rolę tożsamości, samoświadomości, 
określania własnej przynależności do grupy społecznej. Ogólnie można stwierdzić, iż najważniejsza w definiowaniu etniczności staje się percepcja - postrzeganie samego siebie względem innych. Etniczność według F. Bartha to określenie siebie samego i określenie przez innych dokonane dla celów interakcji społecznych.

$\mathrm{W}$ archeologii postprocesualnej S. Jones podjęła próbę opracowania teoretycznych podstaw rozumienia etniczności. Odwołując się do koncepcji habitusu P. Bourdieu starała się przezwyciężyć opozycję dwóch wcześniej istniejących ujęć etniczności. Pierwsze ujęcie postrzega etniczność jako sytuacyjną i dynamiczną formę tożsamości, pojawiającą się w rezultacie zaistnienia wspólnych interesów grupy. Drugie ujęcie opiera się na założeniu, że w grupie etnicznej najbardziej istotne są związki pokrewieństwa. W tym drugim wypadku etniczność jawi się jako rezultat urodzenia się i wychowania w konkretnej grupie spolecznej, charakteryzującej się określoną religia, językiem i normami postępowania.

W swej koncepcji S. Jones w przypadku etniczności jako habitus traktuje środowisko spoleczno-kulturowe, z którego pochodzi człowiek. Środowisko to odgrywa ważną rolę w określaniu tożsamości człowieka, jest to system pewnych możliwości warunkujących funkcjonowanie praktyk, wyobrażeń, innych struktur. Możliwości te nie determinują jednak etniczności. Są zjawiskiem wielowymiarowym, w różnych kontekstach dochodzi do realizacji, do uaktywniania różnych wymiarów etniczności. Stąd możliwe jest posiadanie różnych, istotnych w różnych sytuacjach, lecz emocjonalnie autentycznych etniczności i ich symbolizowanie.

Ta koncepcja podkreśla zatem bardzo sytuacyjny i płynny charakter zjawiska etniczności. W związku z tym podkreślić należy również niezwykłą trudność badania tego zjawiska na podstawie źródeł archeologicznych. Nowe ujęcie etniczności ujawniło, że archeologia nie zawsze jest w stanie wskazać, które artefakty są wskaźnikami etnicznej przynależności. Chcąc przełamać tę niemożność odwołano się do pojęcia ,stylu”.

Niezwykle istotne dla poszukiwań określania etniczności przez pryzmat kultury materialnej jest wydzielenie stylu emblematycznego i potwierdzającego, dokonane przez P. Wiessner. Styl emblematyczny, zdaniem P. Wiessner, to formalne zróżnicowanie cech kultury materialnej, mające wyodrębnionego nadawcę i określonych adresatów, przekazujące jednoznaczną informację o świadomym pokrewieństwie bądź tożsamości społecznej. Styl potwierdzający natomiast, zdaniem Wiessner, to formalne zróżnicowanie cech kultury materialnej, przekazujące informacje dotyczące jednostek.

Według P. Wiessner kontekst i warunki spoleczne są najistotniejsze w formowaniu się stylu. Każde społeczeństwo charakteryzuje się zwyczajowymi sposobami produkcji różnych artefaktów. Te sposoby produkcji dostarczaja podstaw do określenia etniczności jako różnicy „my”/,oni”. Jednak rzeczywisty wpływ ma określony kontekst - warunki, w jakich zachodzi porównanie kulturowe. Pojawianie się i powtarzanie takich kontekstów wplywa na instytucjonalizację poszczególnych różnic i podobieństw. W niektórych sytuacjach, takich jak stan zagrożenia, konflikt lub rywalizacja międzygrupowa, kategorie powtarzalne mogą stać się bardziej stabilne, podczas gdy w innych momentach historycznych cechują się one większą płynnością.

Z powyższego wynika, że etniczność nie zawsze może być identyfikowana na podstawie stylu, a stopień jej zakorzenienia w istniejącej rzeczywistości kulturowej jest zmienny i zależny od zmian kulturowych, zjawisk zachodzących w środowisku kulturowym, interakcji między grupami.

Spostrzeżenia te doprowadziły archeologów - z jednej strony - do sceptycyzmu, traktującego kategorię etniczności jako zjawisko społeczne nieuchwytne w danych archeologicznych, a przez to nie mogące być badanym w archeologii. $Z$ drugiej strony archeolodzy podkreślają olbrzymią rolę badań kontekstualnych, gdyż relacja etniczność - styl zależy od kontekstu społecznego.

Przykładem praktycznej aplikacji tak sformułowanej koncepcji etniczności może być praca poświęcona etniczności Iberyjczyków, autorstwa M. Diaz-Andreu. Autorka ukazała, jak kultura 
materialna - a zwłaszcza ceramika w tym konkretnym, analizowanym przez nia przypadku stanowi cząstkę ksztaltowania i odzwierciedlania etniczności. Wskazuje bowiem, jak garncarze i ich klienci postrzegali etniczność, a wraz z nią różne inne typy tożsamości, na przykład gender, status społeczny. Badania M. Diaz-Andreu dowiodły, że wszystkie przekazy związane z komunikowaniem tożsamości mieszają się, przeplatają się nawzajem na tej samej płaszczyźnie, stąd tak trudno o ich interpretację, jakkolwiek interpretacja ta nie jest niemożliwa.

Dokonana przeze mnie powyżej prezentacja i próba oceny koncepcji etniczności stanowi tylko mały fragment mojej pracy. Ten przykład może jednak uświadomić nam, jak wiele koncepcji dotyczących różnych kwestii społecznych może istnieć w archeologii. Nie ukrywam, że sprawia to wrażenie znacznego rozproszenia zainteresowań badawczych archeologów. Dlatego pożądane wydaje się znalezienie wspólnej płaszczyzny porozumienia dla archeologów tworzących różne teorie. Płaszczyzną wyjściową może być, moim zdaniem, kilka założeń neopragmatyzmu. Zakłada się w nim, między innymi, że nasz intelekt nie jest zwierciadłem, w którym powstaje obraz świata. My tworzymy tylko zdania na temat rzeczywistości. Jedyną rzeczą jaką możemy badać, są związki pomiędzy zdaniami, a nie związki pomiędzy zdaniami a rzeczywistością. Nie ma więc wiedzy obiektywnej. Nie obowiązuje również korespondencyjna teoria prawdy. Prawda jest osiagana jako consensus $w$ rezultacie konwersacji. W konwersacji każdy uczestnik wypowiada własne zdanie, konwersacja zaś daje uzgodnienia i to właśnie one są ową prawda.

Przenosząc myśl neopragmatyczną na grunt współczesnej archeologii założyć należy, że archeolog nie odzwierciedla w swych pracach przeszłej rzeczywistości. Proponuje tylko zdania teorie na temat przeszłej rzeczywistości. Ponieważ nie ma prawdy obiektywnej, archeolodzy powinni dążyć do dialogu. Dialog ten, tworzony między paradygmatami, powinien polegać na przedstawianiu własnych zdań - teorii na temat przeszłości i na tworzeniu uzgodnień, ustalaniu obrazu przeszłych społeczeństw jako rezultatu dialogu.

Równocześnie zdaję sobie sprawę z faktu, iż założenia neopragmatyzmu nie są jedyną płaszczyzną porozumienia, że dialog jest możliwy również na innych płaszczyznach, wykorzystujących choćby pewne założenia filozofii argumentacji. Moje sugestie są tylko jedną z możliwych propozycji, formułowaną w oczekiwaniu na inne propozycje, być może lepsze. 